\title{
Cogeneration - development and prospect in Polish energy sector
}

\author{
Dominika Matuszewska ${ }^{1, *}$, Marta Kuta $^{1}$, and Jan Górski ${ }^{1}$ \\ ${ }^{1}$ AGH University of Science and Technology, Faculty of Energy and Fuels, Department of Thermal \\ and Fluid Flow Machines, al. A. Mickiewicza 30, 30-059 Krakow
}

\begin{abstract}
Next 10-15 years are crucial for condition of Polish energy sector in light of challenges arising mainly from increasing demand for electric energy, need of reducing greenhouse gases emissions and shutdowns of old units. In this situation cogeneration can be one of the most rational way to meet those circumstances. This paper analyzes present development of cogeneration in Poland and its prospect for future.
\end{abstract}

\section{Introduction}

In the next 10 - 15 years the energy sector in Poland is facing important and serious challenges arising mainly from increasing demand for electricity. In a situation where the demand for heat in the country over the last few years is falling, and at the same heat production with over $90 \%$ efficiency is not a big technological problem, the biggest issues of the heating sector seem to be modernization old heating plants, thereby reducing fuel consumption, lowering maintenance costs and reducing overall emissions [1]. From this perspective, the problems in the national power system seem at this point far more pressing and urgent. In August 2015, PSE SA restricted the supply and consumption of electricity in our country. It is worth noting that these restrictions have been introduced due to the decrease in the production capacity of Polish power plants and though they had no direct influence on the individual recipient, they significantly affected on large customers (industrial plants, factories, etc.). The introduction of 20 level of power supply resulted in that the major electricity consumers in Poland could only receive the minimum power which was required to ensure the safety of people and to prevent possible damage of equipment and technological facilities [2].

A few years earlier, it was said about future problems with uncontrolled supply of electric energy and year 2015 showed that the problem is real and with the increasing demand for electricity growing even more serious [3,4,5].

It is estimated that in 2030, Poland will need 46 - 54 GW (depending on available forecasts) of electricity, which now puts before us the question about ways to meet the demand for power in 2030 [6]. Figure 1 presents an estimated installed capacity in 2030 $[\mathrm{GW}]$ based on various reports.

\footnotetext{
*Corresponding author: dommat@agh.edu.pl
} 


\section{Estimated installed capacity in 2030 [GW]}

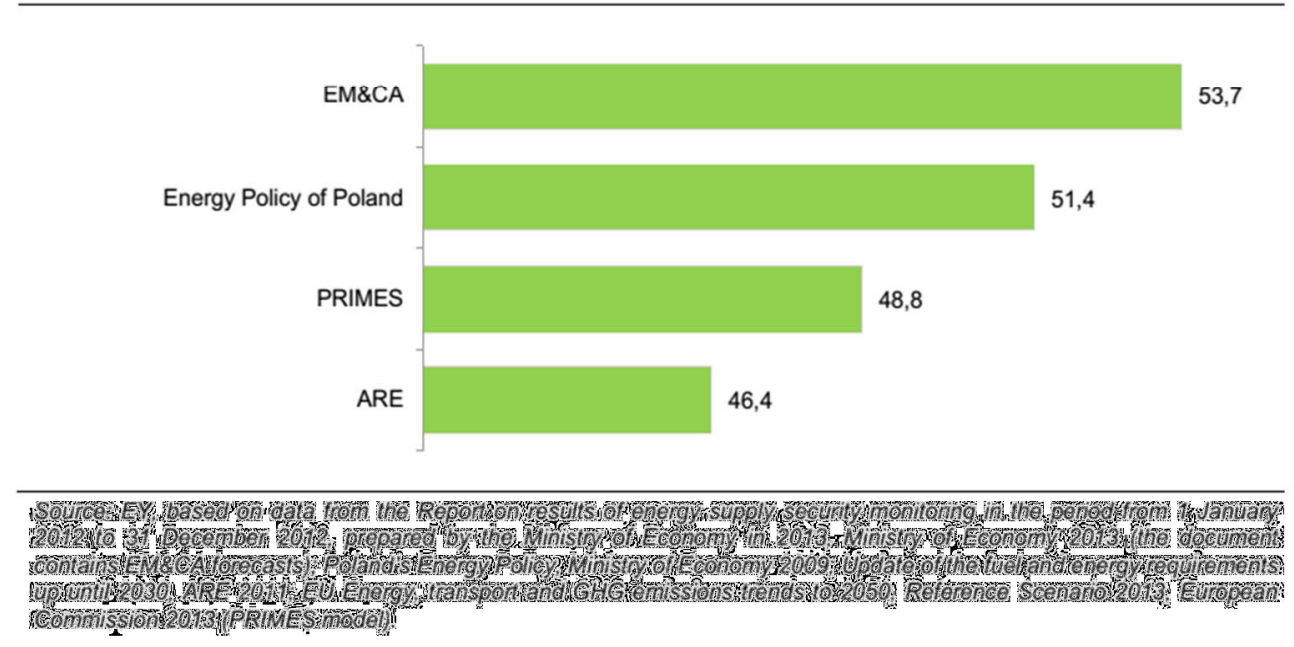

Fig. 1. Estimated installed capacity in 2030 [GW] [6]

The energy sector to meet these requirements must take into account a number of factors including the internal politics of the country, as well as international obligations or technologies available on the market. The development of the energy sector in Poland is closely connected with EU policies, the priorities of which include the creation of an internal, unified and competitive energy market, ensuring security of energy supply, increasing the share of renewable in energy production, reduction of GHG and increase energy efficiency [6].

During the electricity production the energy efficiency is very important and crucial. In case when the efficiency of heat production often hovers around $90 \%$, the efficiency of generating electricity using heat engines is much lower and so in the steam power plants is approx. $46 \%$, in power stations with gas turbines - more than $40 \%$, in power station with combustion engines - around $48 \%$. The value of the electricity generation efficiency is largely limited by thermodynamics, therefore, combined heat and power production seems to be much more rational - both in terms of thermodynamic and economical - way of use the chemical energy of fuels. CHP (i.e., simultaneous generation of different energy) can be successfully implemented in high power systems (eg., industrial and power plants) as well as in distributed systems low power. Both in Poland and in the EU can be observed an increased amount of investments in the construction of cogeneration systems (despite higher capital expenditures). The positives flowing from the construction of such facilities (including the reduction of fuel consumption, operating costs and total emissions) influence significantly on increased interest in this type of installations $[1,7]$.

\section{Development of cogeneration in Poland}

Poland is one of the member countries of the EU, where the tradition of combined heat and power is long, and awareness of the benefits arising from the use of these technologies quite broad. In the 1970 - 1980 years, the share of the production of combined heat in the country grew steadily in industrial and power plants. In the $90 \mathrm{~s}$, it can be observed a decrease in the amount of heat generated in industrial CHP plants, while in the professional CHP plants growth has been maintained, on which undoubtedly were affected by economic 
change and restructuring in the country. Overall, it can be said that the years of the 90th brought in Poland stabilization of heat production from CHP units. The biggest jump of heat production from CHP dates back to the years 1970 - 1995, when it reached a 3-fold increase of the production (approx. $164 \mathrm{PJ}$ ). [8, 9].

As for the electricity production in cogeneration, from 70 s it can be observed its continuous growth with varying intensity, wherein the years 1970-1995 are characterized by the highest growth rates [10].

Table 1 presents installed electrical capacity, total heat supplied, total electricity generation and total share of electricity production in Poland in the period $2006-2012$. The installed capacity of high-efficiency cogeneration in this period was approximately 8.7 $\mathrm{GW}$, while electricity production fluctuated around $27 \mathrm{TWh}$. As for the heat production from cogeneration, it can be seen minimal decline over the years 2006 - 2012, while the electricity production cogeneration has grown steadily and in 2012 amounted to almost $17 \%$ of total electricity production [11].

Table 1. Cogeneration in Poland in the period 200-2012 [11]

\begin{tabular}{|l|c|c|c|c|c|c|c|}
\hline CHP & $\mathbf{2 0 0 6}$ & $\mathbf{2 0 0 7}$ & $\mathbf{2 0 0 8}$ & $\mathbf{2 0 0 9}$ & $\mathbf{2 0 1 0}$ & $\mathbf{2 0 1 1}$ & $\mathbf{2 0 1 2}$ \\
\hline $\begin{array}{l}\text { Installed electrical capacity } \\
\text { [GW] }\end{array}$ & 8.47 & 9.02 & 8.78 & 8.63 & 8.69 & 8.84 & 8.33 \\
\hline Total heat supplied [TWh] & 76.5 & 72.5 & 72.1 & 71.8 & 77.0 & 73.2 & 72.4 \\
\hline $\begin{array}{l}\text { Total electricity generated } \\
\text { [TWh] }\end{array}$ & 26.0 & 27.6 & 26.4 & 26.1 & 27.7 & 27.1 & 27.0 \\
\hline $\begin{array}{l}\text { Total \% of gross electricity } \\
\text { production }\end{array}$ & 16.05 & 17.30 & 16.91 & 17.19 & 17.57 & 16.58 & 16.68 \\
\hline
\end{tabular}

The date from the table 1 are presented in graphic form below in Figure 2.

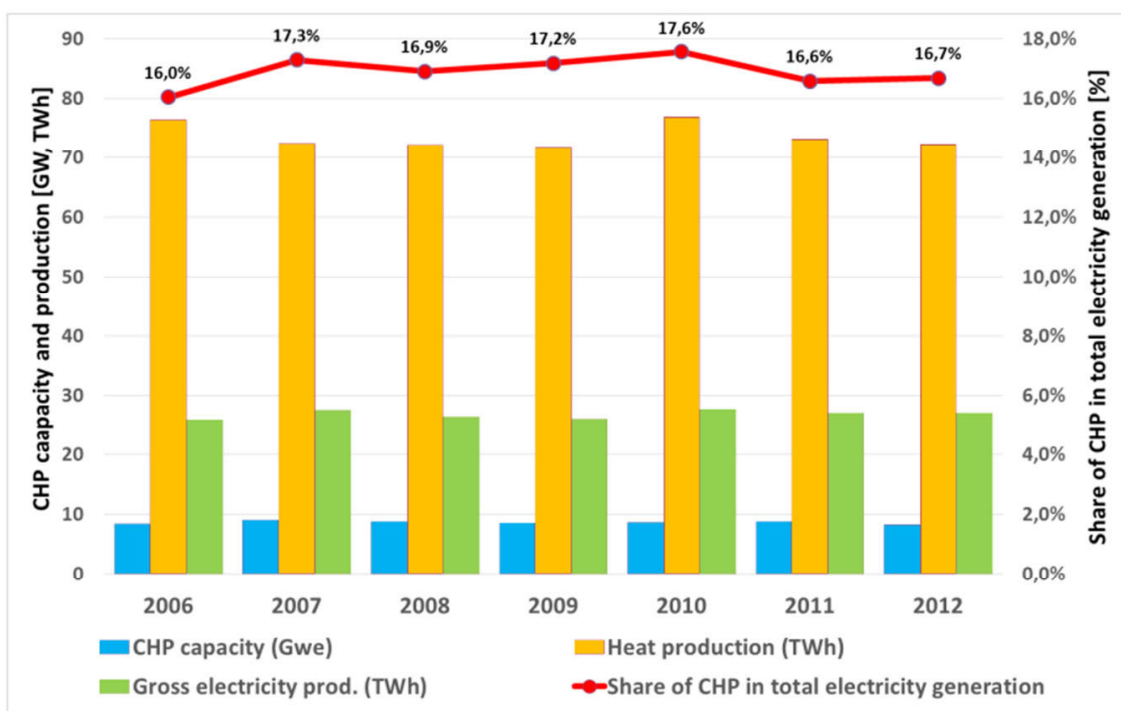

Fig. 2. Electricity and heat production in high-efficiency CHP and share in total electricity production in the period $2006-2012$ [11] 
In 2014, heat production in Poland was about 393.2 thousand of TJ, of which a significant amount was used for their own needs, while 60\% (taking into account transmission losses) went to customers connected to the network. It is worth mentioning that more than $64 \%$ of the heat production was produced in cogeneration with electric power (Figure 3) [12].

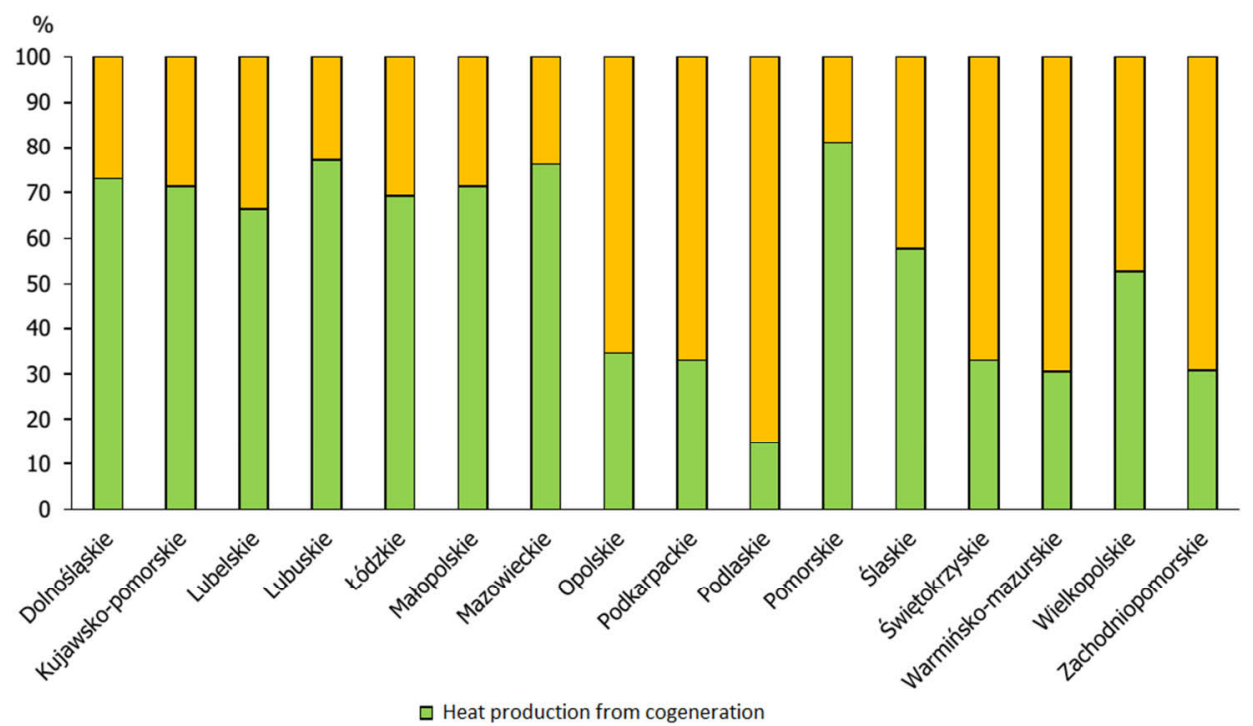

Fig. 3. The share of cogeneration in heat production for different regions in Poland (2014) [12]

The share of cogeneration in heat production varies for different regions in Poland and so was the highest in the regions of Pomerania (over 80\%), Lubuskie, Mazowieckie (over 75\%) and the lowest in the region of Podlasie (below 20\%).

The electricity production in cogeneration (with use of steam turbines) in Poland is mainly based on the coal technologies (about $88 \%$ ). The share of electricity generated in gas cogeneration units (combined cycle with a gas turbine CCGT) and low power units of less than 1 MW (as internal combustion engine) was in 2012 less than $12 \%$ of the electricity generated in cogeneration [11]. Production of electricity from cogeneration is shown in the following figures (Figure 4). 


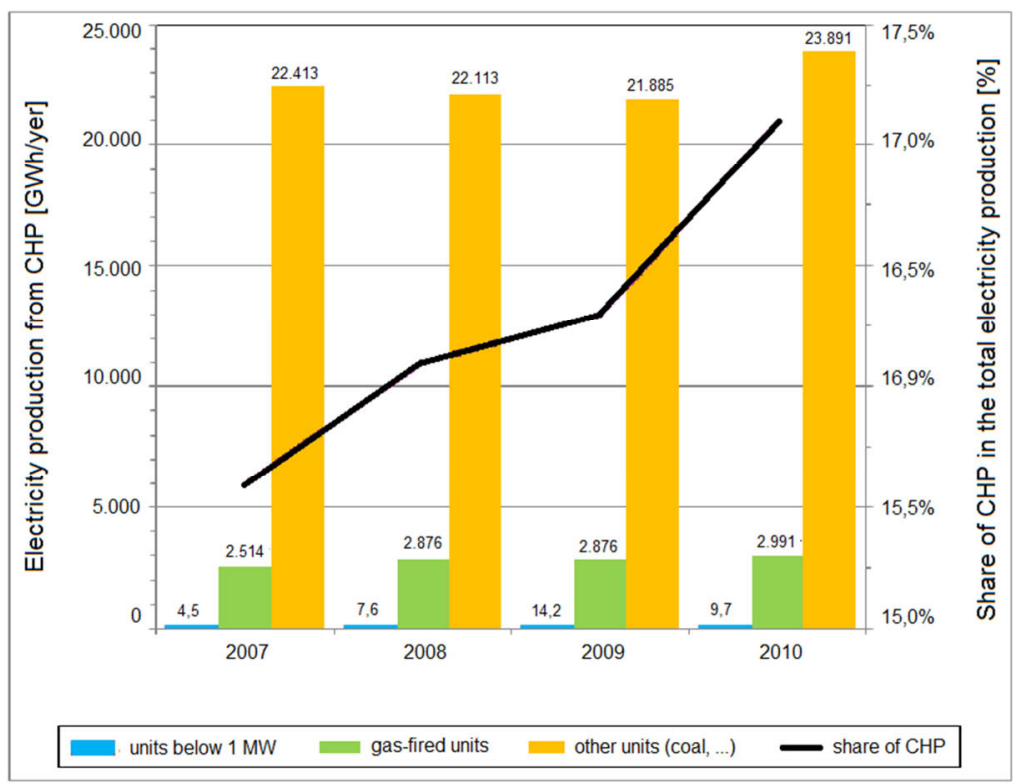

Fig. 4. Electricity production in high-efficiency CHP and share in total electricity production [11]

\section{Prospect of cogeneration in Poland}

Cogeneration is considered to be one of the key technologies that can help meet the main goals of energy and climate policy in Poland, which include, among others, improving energy efficiency, increasing the use of renewable energy sources and reduce greenhouse gas emissions and dust $[1,6,11]$. It seeks to increase the efficiency of energy conversion of fuel used to produce electricity and heat, which is very desirable from both energy, environmental and economic points of view. [1, 13]. The figure 5 illustrated mechanism of obtaining a fuel savings by using cogeneration, and thus indirectly influence the emission of harmful substances into the environment. Government estimates show that the use of cogeneration potential reduce primary energy consumption and emissions $\left(32 \mathrm{Mt} \mathrm{CO}_{2}\right)$ and thus help achieve the objectives set out in the Climate and Energy Package $2020[6,11]$.

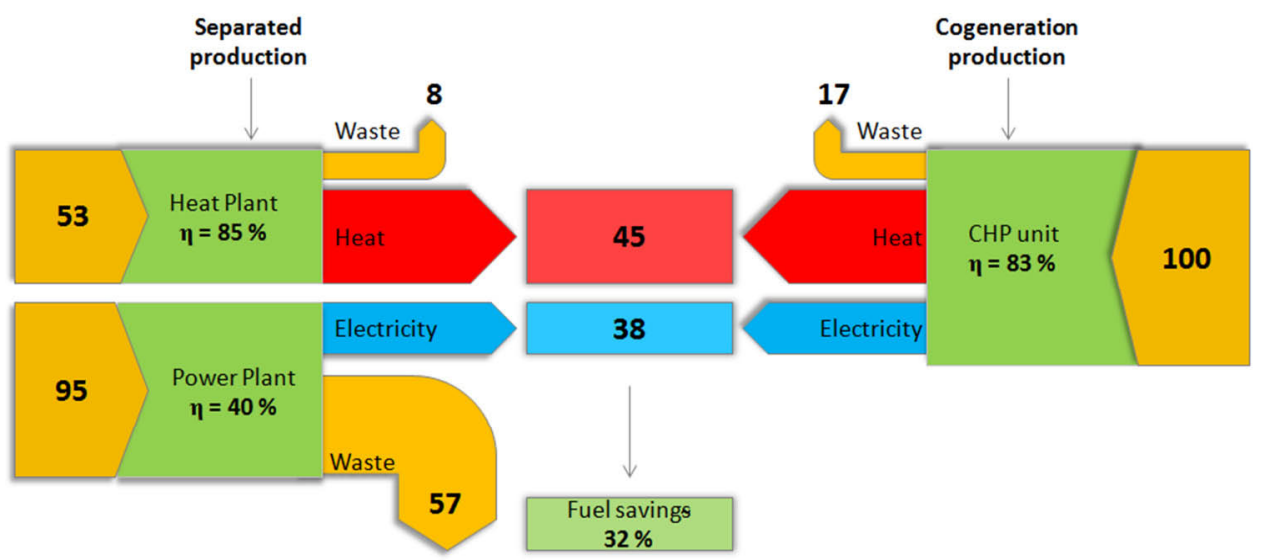

Fig. 5. The mechanism of obtaining a fuel savings in cogeneration 
In near future, the energy system in Poland will face with problems of capacities shutdowns, on what will be affected - in addition to the EU climate policy - the age and condition of existing units. In 2013 the vast majority of units generating electricity were power plants working over 30 years - having a total installed capacity of $18 \mathrm{GW}$ which represents $58.65 \%$ of the total installed capacity (Figure 6).

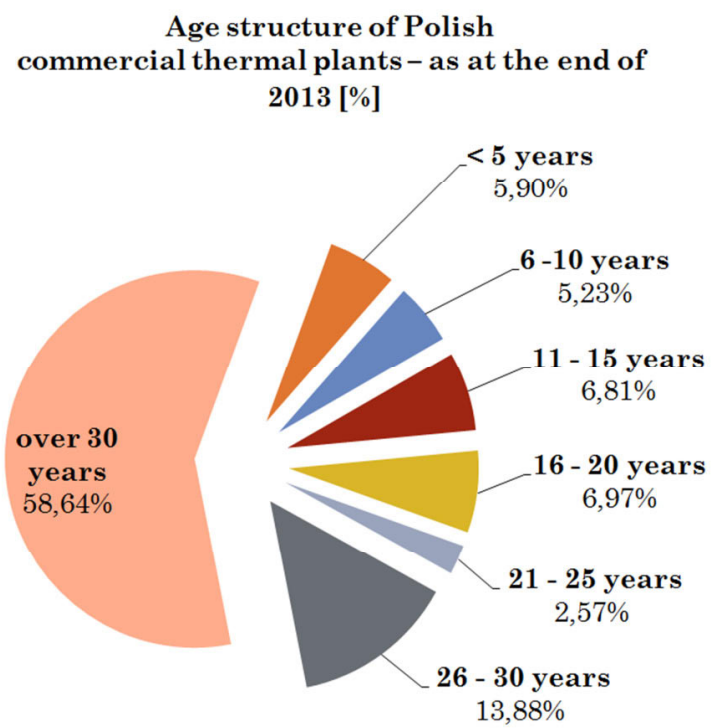

Fig. 6. Age structure of Polish comercial thermal plants - as at the end of 2013 [\%] [6]

The scale of the planned shutdowns of currently operating power plants and the estimation of installed capacity in 2030 (depending on the forecast: 46-54 GW) open up huge investment opportunities in new generation capacities. Taking into account the assumptions of Climate and Energy Package (about greenhouse gases emissions and renewable energy), cogeneration and hybrid systems based on renewable energy sources [14] may be a good option for power plants based on fossil energy sources.

The technical potential of heat supply from cogeneration varies depending on the forecast for 2020 was estimated at approx. 206 PJ. New projections show that Poland has the potential to achieve $12.051 \mathrm{MW}$, which would increase by more than 4,000 MW compared to 2010 (Figure 7). It is estimated that the level of production of electricity in cogeneration by 2030 will increase from 21 TWh to 48 TWh or $22 \%$ of total demand for electricity. Forecasts also indicate that approx. $20 \%$ of installed capacity in cogeneration will be from renewable sources [11]. 


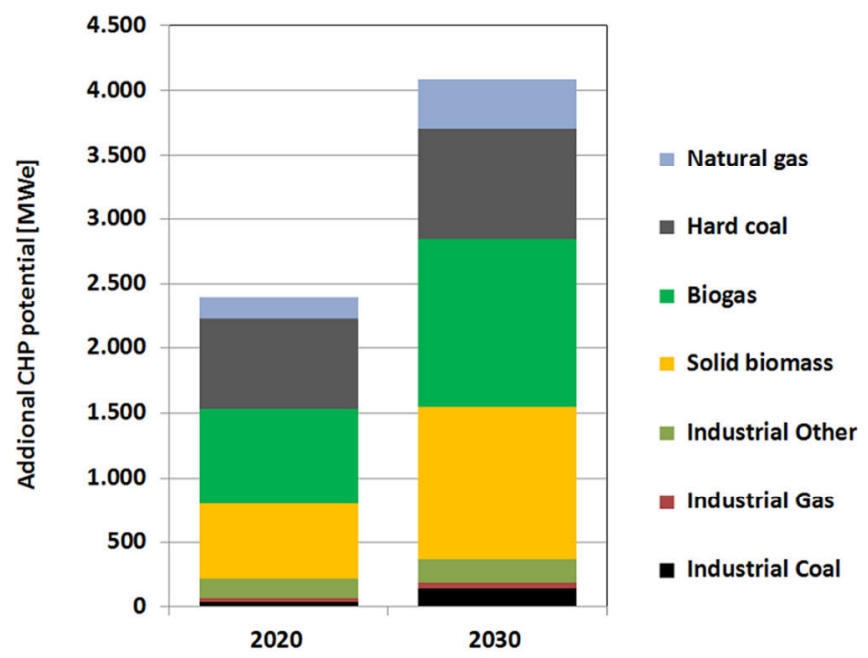

Fig. 7. Additional CHP potential till the year 2030 [11]

\section{Conclusion}

Cogeneration is a very efficient way to produce electricity and heat. CHP systems to produce a certain amount of electricity and heat need less fuel than if production is from separated units. This influence not only on fuel savings but also on lowering operating cost of such unit and on reduce of greenhouse gases emissions and environmental pollution.

In summary, Poland has a long tradition in the combined production of heat and electricity. Despite this, there is still great potential for new cogeneration units especially considering the future of capacity demand forecast and the necessity of withdrawal of the old, outdated units. The forecasts predict that the share of cogeneration in heat and electricity will be growing. However, greater emphasis will be put on unit cooperating with renewable energy sources (approximately 20\% of installed capacity in cogeneration in 2030 will be from renewables).

This work was supported by AGH - University of Science and Technology (Project 11.11.210.216).

\section{References}

1. J. Skorek, J. Kalina, Gazowe uktady kogeneracyjne (Wydawnictwo NaukowoTechniczne) (2005)

2. PSE SA, Statement from $10^{\text {th }}$ August 2015 about a threat to the security of electricity supply, taken actions and measures to remove the threat and prevent its negative effects, and the introduction of restrictions on the supply and consumption of electricity. (2015)

3. Poland Energy Report, Enerdata (2012)

4. Ministry of Economy, Report on results of energy supply security monitoring in the period from 1 January 2011 to 31 December 2012 (2013)

5. Ministry of Economy, Report on results of energy supply security monitoring in the period from 1 January 2013 to 31 December 2014 (2015)

6. Report of EDF, Is any divresification needed? poland's potenial electricity mix in 2030 in the light of internal and external deteminants (2014)

7. J. Szargut, A. Ziębik, Podstawy energetyki cieplnej (PWN Warszawa) (1998) 
8. J. Marecki J., Wokół Energetyki (2005)

9. J. Kalina, Small-scale cogeneration in Poland. 2003 market report. The work package WP2 (title Cogeneration and eco-buildings) of the OPTI_Energy Centre of Excellence, Fifth Framework Programme of the European Commission (2003)

10. J. Lewandowski J., et al., Program rozwoju kogeneracji w Polsce. (Uczelniane Centrum Badawcze Energetyki i Ochrony Środowiska) (2010)

11. CODE2 Cogeneration Observatory and Dissemination Europe D5.1 Final Cogeneration roadmap for Poland (Jozef Stefan Institute) (2014)

12. A. Buńczyk A., Thermal Power in numbers - 2014 (URE) (2015)

13. M. Sołtysik, K. Mucha-Kuś, Acta Energetica 3/24 (2015), 97-102

14. J. Kiciński, P. Lampart, Acta Energetica 2/2 (2009) 